\title{
IN-SERVICE TRAINING IN THE NIGERIAN PUBLIC SERVICE: IT'S IMPLICATION FOR NATIONAL DEVELOPMENT
}

https://doi.org/10.47743/jopafl-2021-22-06

\author{
Gbosien Chris SOKOH \\ Department of Political Science \\ Delta State University Abraka, Delta State, Nigeria \\ sokohgc@gmail.com
}

\begin{abstract}
Administrative activity is a universal phenomenon and its process is a function which is performed in every sector. Today, administrative activities are no longer simple. They have become so complex and specialized that mere commonsense is not enough to carry them out. Besides, the nature of administrative activities is constantly changing. Hence, there arises the necessity of both in-service and post-entry training. However, training had not been given due importance till recently. Even now it is still generally considered one of the lesser developed areas of public personnel administration one in which much remains to be done. The thrust of this study is to examine human resources training development and utilization in the Delta State public service and its implication on national development. The theoretical framework for this study is system approach to training. The study utilizes the methods of descriptive analysis and synthesis of scientific literature to explain the in-service training of staff in Delta State public service. In the context of the inservice training therefore, this study finally proposes recommendations for improving in-service training in Delta State public service.
\end{abstract}

Keywords: In-service Training, National Development, Public service, Delta State, Nigeria

\section{Introduction}

The public service is the power-house of national development all over the world. The developed countries of the world like United States of America, Britain, Germany and France owe their development to the initiative, commitment and expertise of their public servants. Nigeria cannot be an exception; however, if public servants in Nigeria are to fulfill this mission, there must be conducive political, economic and social environments that predispose them to success. Administrative activities are no longer simple. Tjhey have become so complex and specialized that mere commonsense is not enough to carry them out. Besides, the nature of administrative activities is constantly changing. Hence, there arises the necessity of both in-service and post-entry training. However, training had not been given due importance till recently. In the words of Bhagwan and Bhushan (2012), 'Even now it is still generally considered one of the lesser developed areas of public personnel administration, one in which much remains to be done'. The country abundant material resources must be harnessed and utilized for the benefits of her people. This calls for sound professional training and inculcation of correct values in the public service. Manpower training and development is therefore a sine-qua-non after workers have been selected and placed in the public service. The objective of the study therefore, was to examine human resources training, development and utilization in the Delta State public service and it's implication on national development. 


\section{Research Objectives}

The specific objectives of this study are to investigate the nature of staff training and development policies programmes, status, facilities for implementation and their relationship with pre-stated objectives of the public service. The study intends to relate training and development to staff morale in the public service. In the light of the above, the study intends to construct a staff training and development programme aimed at reducing the administrative, social, psychological and economic problems of the public service. Further, the study would expose the inadequacies or otherwise of staff training and development programmes in the public service in Delta State, Nigeria. This study also highlights the advantages of training and development and their implication for national development in Delta State, Nigeria and enables us to know the staff cadre that enjoyed more training to the disadvantages of others and the reasons why some staff stagnated on a particular post for long period of time.

\section{Materials and Methods}

The study utilizes the methods of descriptive analysis and synthesis of scientific literature to explain the in-service training of staff in the Delta State public service.

\section{Training}

Training is defines as "the process of developing skills, habit, knowledge and attitudes in employees for the purpose of increasing the effectiveness of employees in their present government positions as well as preparing employees for future government position” (Bhagwan \& Bhushan, 2012). Its dictionary meaning is practical education in any profession, art or handicraft. In public administration, it means a conscious effort made to improve or increase an employee's skills, powers or intelligence and to develop his attitudes and schemes of values in a desired direction. Training can also be defined as an organized and coordinated development of knowledge, skills, and attitude needed by an individual to master a given situation or perform a given task within an organizational setting (Orobor, Ogieva \& Abah, 2006).

Training is to be distinguished from education because it has comparatively a narrower scope. Education can be explained as the complete upbringing of the individual from the childhood, the formation of character and of habits, and manners and of mental and physical aptitude. No doubt both are closely related to each other and even overlap each other. Koontz (2002) has clearly distinguished between the two. He remarks, 'education is intended to enable an aspirant to pass an examination or otherwise to show fitness for appointment or more broadly to develop the knowledge and qualities of mind which will make for subsequent success ... By contrast in-service training is directed towards individuals who are actually at work. Such training is a recognizable investment in long-term service'. The specific objective in view is performance (Bhagwan \& Bhushan, 2012). Education makes a people easy to lead, but difficult to drive, easy to govern but impossible to enslave (Baugham, 1987). But training is essential not only for effecting efficiency of administration but also for broadening the vision of the employees. It teaches him precision, makes him self-reliant and independent and develops in him capacity to take decisions and arrive at judgments. 


\section{Development}

Development is the "process of providing employees with opportunity to grow on the job. This entails the acquisition of wide experience and increasing confidence as a result of exposures to varied and tested responsibilities in order to make the employee reach the peak of his profession of employment” (Williams \& Huber, 1966). This support the assertion of Bateman and Snell (2011) who posit that "development is a process of helping managers and professional employees learn the broad skills needed for their present and future jobs”.

\section{Public Service}

The public service is seen as an organized body of men and women elected into office or employed on fulltime basis by government on behalf of the state and drawing a regular salary or wage from public funds for the purpose of formulating and executing public policies, programmes and projects. According to Mukoro (2020:39), public service is "a very wide concept that covers everybody that works for and is remunerated by the government. It does not matter whether they are elected, appointed or recruited as bureaucrats. So long as their duties, responsibilities and actions resolve around the business and dynamics of government; they are public servants”.

\section{In-service training}

In-service training, as its name indicates, is "a sort of training which is imparted to the candidates after their selection to the public service. The objectives of in-service training were very well explained by the Assheton Committee (UK) in its report submitted in May, 1944. Briefly speaking, this type of training stimulates the employees to make best efforts and to improve their performance. It boosts their morale and makes them attuned to the new tasks of onerous nature. In-service training is a type of training programme in which employees are allowed to undergo formal training in educational institutions or training establishments in order to increase the skills on their job” (Orobor, Ogieva \& Abah, 2006). In-service training may be granted with or without pay to senior and junior members of academic, administrative and technical staff of an institution, who are on regular appointment. It is, therefore, desirable that a comprehensive system of in-service training may be adopted. In the words of Bhagwan and Bhushan (2012) 'no matter how well-grounded an employee may be in the general subject to which his work relates, there is much for him to learn in respect to the particular duties of his position'. In addition, Administrative Reforms Commission in its recent report on the importance of training stated that training should prepare the individuals civil servants not only for performing their present job well but also for shouldering higher responsibilities and meeting new and complex challenges in future.

\section{Importance of In-Service Training}

Training plays a vital part in public administration. It is essential not only for effecting efficiency of administration but also for broadening the vision of the employee. It teaches him precision, makes him self-reliant and independent and develops in him capacity to take decision and arrive at judgments. Training has, therefore, been described as a continuous process. It enables an employee to adjust himself to the new situation and 
comprehend the goals and values of the organization in which he is to work. Assheton Committee on the Training of the Civil Servants in U.K (1944) has very well explained the main importance of in-service training. 'In any large-scale organization, efficiency depends on two elements, the technical efficiency of the individual to do the particular work allotted to him and the less tangible efficiency of the organization as a corporate body derived from the collective spirit and outlook of the individuals of which the body is composed. Training must have regard to both elements'. The main aims of training as explained by the committee are as follows:

1. It endeavors to produce a civil servant whose precision and clarity in the transaction of business can't be taken for granted.

2. It helps attuning the civil servant to the task he is called upon to perform in a changing world. It in other words, helps him to adjust his outlook and methods to the changing needs of now times.

3. It saves the civil servant from becoming a robot-like mechanically perfect civil servant. He is made aware of his work and the service that he is required to render to his community.

4. It not only enables an individual to perform his current work more efficiently but also fits him for other duties. It develops in him capacity for higher work and greater responsibilities.

5. It pays substantial regard to staff morale as the latter have to perform tasks of a routine character throughout their lives.

6. Besides these importance explained by Assheton Committee, a few others can also be enumerated:

7. For the performance of certain peculiar activities pertaining to the government, training plays a significant part. For instance, government must make a provision for training police personnel, firemen and food inspectors, etc.

8. Training helps the employees to become people-oriented and inculcates in them respect and regard for the public. Even Assheton Committee had observed thus, nothing could be more disastrous than that of the civil service and the public should think of themselves as in two separate camps. The inculcation of the right attitude towards the public and towards business should therefore be one of the principal aims of civil service training.

9. It also broadens the vision and widens the outlook of the employees by explaining to them national objectives and exhorting them to make substantial contribution towards their realization. The function of training is to help employees grow, not only from standpoint of mechanical efficiency but also in terms of the broad outlook and perspective which public servant need.

10. It improves the tone and adds to the quality of organizations. Since it enhances the efficiency of the employees and develops their capacities, the efficiency and prestige of the department goes up.

11. It fosters homogeneity of outlook and esprit de corps in the employees.

12. Effective administration requires effective training towards organizational goals

because of the harm may be expected when people are left to train themselves without effective guidance or support.

Methods of In-Service Training

Broadly speaking, there are three methods of in-service Training: 
a. The service may on their own accord undertake training, making use of their own staff. In U.K each department carries on its training programme. There are three variations of this method:

b. The government may start a training school of its own. For instance, the Union Ministry of Personnel in India is running its own National Academy of Administration called the Lal-Bahadur Shastri since 1972 at Mussoorie. The Academy has been functioning since September 1, 1959 for imparting training to the fresh personnel. The Academy offers three types of courses:

i. A one-year course for the fresh personnel officers to cover the syllabus prescribed under the All India services Probationers Final Examination.

ii. A six-week refresher course for senior officer of 10 to 15 years standing.

iii. A continued course of five months for all the India services and the central services class 1 for imparting training of foundational subjects.

iv. iv. These courses aim at widening the outlook of the trainees. Such a general courses imparts general education in liberal arts to the personnel recruited for posts of specialized nature.

The Government may request an outside training institute to impart requisite instructions. This is called internship System. In U.S.A, the National Institute of Public Affairs undertakes internship training to the new entrants in federal services. In India, Institute of Public Administration at central level and state levels are doing the similar job.

\section{Theoretical Framework}

For the purpose of this work, this study adopted the system approach to training. In this approach, the development of a training programme is linked to the development of a weapon system. Here, the system engineer begins with an operational requirement, a precise statement of the objectives to be achieved, by the system. The system engineer then works backward from these objectives to produce an arrangement of sub-system which, when operated according to some operational plan, will fulfill the requirement.

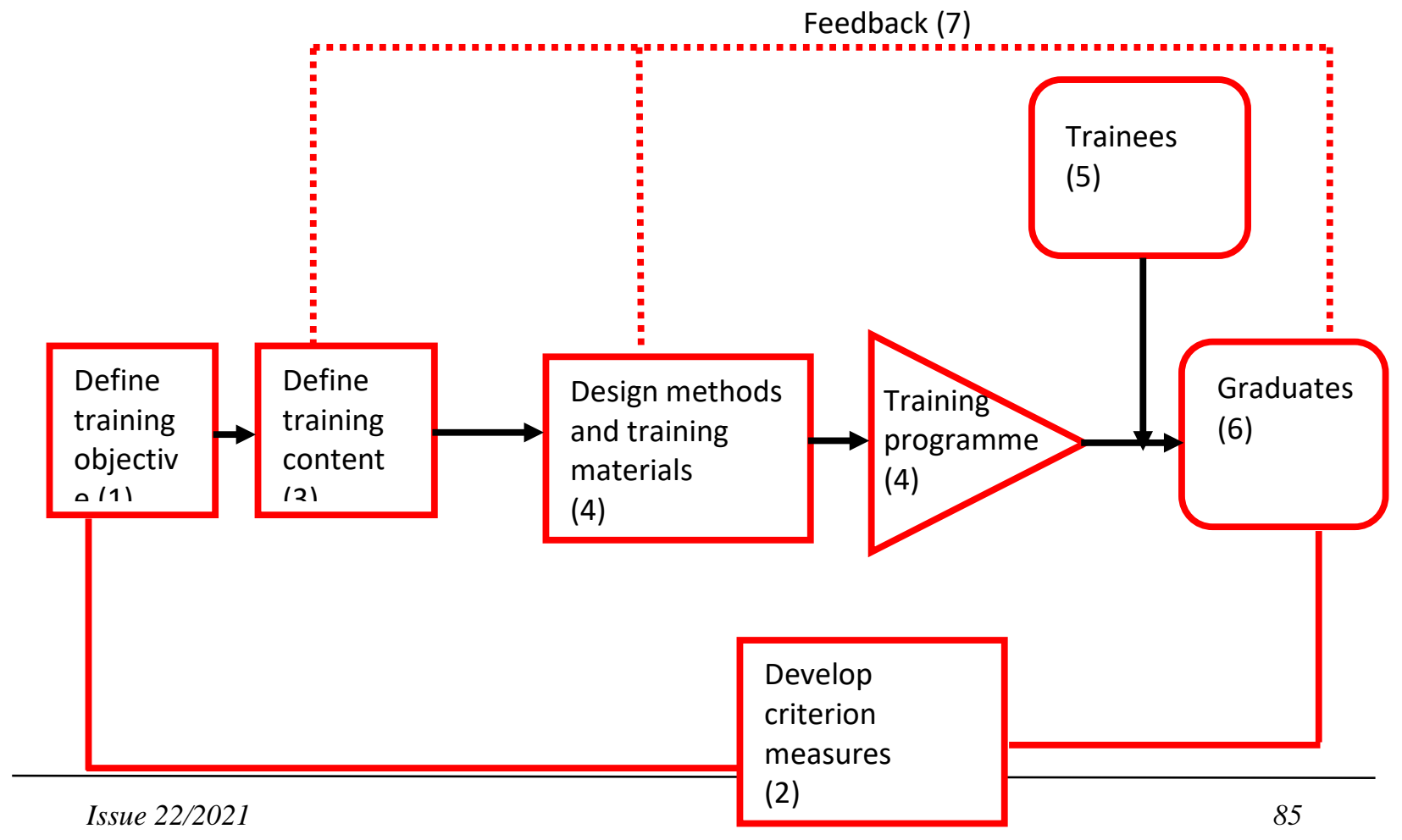


Source: G.A. Eckstrand, current status of the Technology of training AMRL document, technical report step 3, 1964, 64-86.

The design of a training system can proceed in the same manner. The behaviour which men must exhibit on the job becomes the objective which must be achieved by the training system. The job of the training designer, then, is to select the sequences of a series of learning experiences which will produce the desired behaviour. A testing (evaluation) phase is required to assure that the training programme designed succeeds in producing men capable of performing as specified. The application of the system approach to training can best be understood by examining the diagram taken from Eckstrand (1964). It involves seven major steps:

Step 1: Define training objectives;

Step 2: Develop criterion measure for evaluation of training;

Step 3: Derive training content;

Step4: Design methods and training materials;

Step 5: Integrate training programme and trainees;

Step 6: Compare graduates to criteria standards set in step 2; and

Step 7: Modify step 3 and 4 based on the results.

The advantage of the system approach is that it helps the trainer in making his decision. He is able to understand and keep in mind the total training process as he tries to accomplish his objectives. The system approach to the study of the organizations focuses on the system as a whole, the environment of the system, the interdependent relationship between parts of the system and the dependency for the system to strive for survival by negotiating with its environment. As observed by Koontz et al. (2002), "the advantage of approaching any area of inquiry or any problem as a system is that it enables us see the critical variables and constraints and their interactions with one another. It forces scholars and practitioners in the field of management to be constantly aware that one single element, phenomenon or problem should not be treated without regard to its interacting consequences with other elements”.

The system approach was first developed in the biological and engineering sciences before it was adopted by social scientists in explaining social and organizational phenomena. David Easton utilized the approach in his system analysis of political life in 1965; Katz Daniel and Khan Robert also used the open system approach in studying the social psychology of organizations in 1966 and G.O. Nwankwo also adopted the system approach in his book education and training for public management in Nigeria (Orobor, Ogieva \& Abah, 2006). follows:

The major components involved in the system theory can be summarized as

1. A system can be perceived as whole with its parts and their interdependent relationships.

2. As system has its boundary and can be viewed in terms of its relationships with other systems.

3. Systems have sub-systems and are also part of a supra system.

4. A system can be regarded as either open or closed. According to Koontz (2002), a system is regarded as open if it exchanges information, energy, or materials with its 
environment as it happens in biological or social system, while it is regarded as closed if it does not have such interaction with the environment.

5. A system interacts with its environment in terms of process that involves input, conversion and output of energy, information and materials. A system tends to re-energize or modify itself through the process of information feedback from the environment.

6. In order to survive, an open system moves to arrest the entropic process by importing more energy from its environment then expended and by storing energy it can acquire negative entropy. As Katz and Kahn (1966) further explain the entropy process as a universal law of nature in which all forms of organizations move toward disorganization or death.

\section{In-service Training in the Delta State Public Service}

In public service organizations, workers are employed after careful examination and selection process. The examination could take the form of written tests, oral test, physical and mental test, trial on the job and in addition the checking of certificates and character reference from former schools or places of employment. The goal is to obtain the right person for the right job. In spite of the above initial step, it is often observed that after the workers have been selected and placed on the job, there is need for further training if they must achieve full productivity for effective service delivery. Manpower training and development provision likely to promote workers productivity as it is geared toward addressing at least two problems:

1. Failure of our educational system to adequately meet the training needs of our public service and

2. Failure of some public service workers to adjust to work in the organization.

The training programme should thus, provide the public service organization with its specific training needs as well as the general needs of the society. In doing this, there should be a conducive environment which provides the resources as well as the supervision. Thus, the ministry provides the necessary resources such as finance and materials while the superior provides the encouragement, opportunity and feedback through the performance skills and attitude to work. The training process should be based on the needs of the service and the workers should be made to identify with these needs.

\section{Problems of In-Service training in Nigeria Public Service}

The problems of training and development of human resources are enormous and call for concern. French (1978) highlighted a number of problems facing the training and development process in organizations. Quoted in Onah (2003), some of these identified problems include the following:

i. How can training needs be determined and how can training need be distinguished from an organizational need that can be satisfied in some other ways?

ii. How can people be motivated to increase their capabilities?

iii. What are the relative utilities of various training methods and devices?; and

iv. To what extent can the achievement of objectives of the training programme be determined?

An untrained human resource is a liability to a dynamic public service organization as he not only applies the wrong knowledge to others coming after him and those he happens to be supervising. As observed by Akpan (1979) "an untrained man in the modern 
world may be a menace to the society. He is a quack; he knows only the laws of things, he has no ideas of (their) why. Hence if there is any trouble anywhere break in machine or a mistake in a ledger all he can do is to fumble and punch up trouble anyhow, leading to a more serious breakdown or greater confusion. Really there is no place for the untrained workers, or even the intelligent amateur, in these days of specialized work. Also, the traditional personnel management functions of recruitment, placement, wages administration, employee welfare, discipline and industrial relations, staff training and development tend to receive far less attention than others herein mentioned”. It is for this reasons that Ubeku observed that there are many organizations in this country that regard training and development as expensive ventures and avoid them like the plague. What such organizations are interested in are the immediate returns. But in a changing world of which Nigeria is a part, this attitude cans no longer hold good (Ubeku, 1975 as cited in Onah, 1992).

Even in organizations where the need for employee training is recognized and a lot of time and money is committee to staff training and development, the exercise is often inappropriate, haphazard or premised on faulty diagnoses of organizational training needs. In other situations, where training happens to occur, deployment of staff so trained may be without regard to the skills the staff acquired, leading to frustration of personnel so trained and also general inefficiency in the public service organization. Today, the public service in Nigeria is fond of this practice. The workforce is generally understaffed, under tapped, underutilized, and therefore falls short of its anticipated contribution to the realization of organizational goals. Therefore, this study at this point investigate the nature of staff training and development and the reason for low interest in them in the public service organization in Delta State and Nigeria at large. Also, the section intends to know how these problems affect the morale of all categories of staff in the public service. The following are the specific questions (problem) of this study: Why have the governments in Delta State and Nigeria at large been seemingly paying inadequate attention to staff training and development?

a) If the public service is now forced to reduce their workforce, will the highly reduced number cope with the work which is ever increasing?

b) If stagnation and its attendant frustration exist, are they traceable to inadequate training and developments?

c) Are the training and development programmes available based on the needs of the public services?

d) Is staff turnover and wrong placement related to the nature of staff training and development programmes of the public services?

\section{Research Findings}

First among the findings of this study agree with the general opinion that the Nigeria public service's biggest problem is shortage of specialized manpower and that the solution is quantitative, that is to greatly expand the education system at all levels in order to bridge the manpower gap. Today, the result is proliferation of training institutions like universities, polytechnic, colleges of education and other similar institutions. There are at present 153 universities in the country, federal, state, and private. There are 112 polytechnics in the country and several colleges of Education. With these numbers of 
training institutions, is a manpower shortage really the public services greatest problem? Is massive expansion of formal education really the solution? We believe that the problem is qualitative rather than quantitative.

For manpower or human resources' training and development to become meaningful and impact positively on people, the qualities of training received by many of our public servants have colonial orientation. Western education rather than fostering clear ties between the recipients and their less privileged rural majority, whom they are supposed to serve, has become a tool for social alienation. The specialist public servant by virtue of his training automatically graduates to a distinct social class and enjoy enormous privileges, wealth and prestige. The public servant is remote from the masses as a whole and therefore unable to identify with the basic problems of poverty whose eradication is the essence of training and development. The desire for job security has made service to the nation a matter for secondary consideration by many of our specialists. The survival instinct in man makes him to plan for the rainy day.

Where his employer fails to guarantee him basic safety requirements, the tendency is for him to seek for the satisfaction of these needs through other means. Thus, the issues of job security become important. The best trained officer will certainly not perform well if his interest is at variance with that of the organization. Primordial loyalty and the fear of retiring into penury after a meritorious career in the public service often work against good governance and national development. This fear is largely responsible for corruption in the public service and brain drain. In the United States alone there were between 150,000 200,000 Nigerians by 2015, many of whom are highly trained in various fields. Within the same period, there were no less than 500 Nigerian medical doctors in Europe and America and the reasons given for the drift to other countries range from poor remuneration to lack of necessary working tools. A nation that has invested so much to develop its human resources is obliged to create avenues for the full utilization of those resources. Unfortunately the governments of Delta State and Nigeria at large have failed in this direction and the result is a demoralized and frustrated public service where personal interest overrides patriotism.

The desire to seek livelihood from the westernized public service bequeathed to us by Europeans is responsible for the craze for paper certification. The qualification for job in the public service is possession of paper certification even for less skilled positions. The result is that the majority of intelligent rural Nigerians are neglected in the public service. These neglected rural folks are the backbone of the country's manpower. There is a distinction between literacy and education. Nyerere explained that the fact that pre-colonial Africa did not have schools did not mean that children were not educated. They learned by doing. In the house and in the farm, they were taught the skills of the society and the behaviour expected of its members. Nigeria's rural majority have an acquired intelligence which is ignored or belittled by government as if it were not relevant to national development. The universal basic education is seen as an alternative to national education instead of improvement on it.

The craze for paper qualification has made nonsense of training system. The certificate is seen as meal ticket and many Nigerians are prepared to go to nay extent to acquire it, fair or foul. It is therefore not surprising to find a diploma graduate in secretarial studies who cannot transcribe a public speech or a higher national Diploma in Human 
Resource Management or Public Administration who cannot write a memo. This spells doom for our public service and the nation in general.

If we accept Nyerere's view that the masses of Nigerians are educated, then the neglect of the vast pool of untapped manpower can be explained by the fact that the elites are bent on preventing outsiders from encroaching on their privileged position. How can we rationalize the demand for at least a first school leaving certificate for labourers or security guards in the public services? In the meritocratic American and British societies, Universal education has fairly graded the society into levels of intelligence but Nigeria has not undergone that process. The Chinese realized this early in their history that many people who do not do well in formal education can make useful contributions to society and this is why their public service is doing well, this is why our progress is slow.

The close career system in operation in Nigeria is another serious challenge to the performance of our public services and good governance. The system does not allow for infusion of specialized manpower from the private to the public sector at the very high level. The implication is that when there is need for specialized hands in the public service at the very high level such a hand is not really available; government operation suffers considering the high cost of training those already well trained and failure to allowed specialized hands to switch over to the public service from the private service at any level. This is one area which the American public service has excelled and Nigeria can learn from their experience.

The developed countries are where they are today because of their breakthrough in science and technology. Unfortunately, the government does not place high premium on research in Nigeria. In the year 2000 research boosted the economy of the United States of America and neighboring states by $\$ 7.4$ billion. The educational curriculum in Nigeria is richer and more diverse than before but, indifferent teaching, lack of infrastructure and poor funding combined to lower the standard of training. In the 1950's Sahya Onabamiro, a Nigerian micro-biologist discovered a type of bacteria known worldwide and named after him. Onabamiro's discovery was a solo effort. In the 1970's students at Obafemi Awolowo University discovered a device for making pounded yam but because there was no patronage for it, the patent right was sold aboard to be developed by people who don't eat pounded yam. This is quite unlike the United States of American where the most spectacular advance in science and technology have been researched and developed by their universities in collaboration with government and its institutions and the private sector. It is not surprising that $70 \%$ of Mobel prize winners and a third of learned articles in science and engineering worldwide are form the United States of American. For training to contribute to national development in Delta State and Nigeria at large, the governments must be overtly committed to investing much in research work.

\section{Recommendations for Improving In-service Training in Nigeria Particularly Delta State Public Service}

Nigeria and indeed Delta State is blessed with abundant resources which if harnessed will make the country one of the leading nations of the world. The following suggestions if implemented will help in transforming the country:

i. There should be conscious effort made by the relevant authorities to improve on the quality of training given in our different institutions. Citizenship and leadership 
education should be made compulsory in all our training institutions. As Machel noted, there is the need to establish new relations between teachers and pupils based on the principle that to teach is to learn and that one learns in order to produce in a collective effort. In this way the distorted social role of training, discrimination and corruption which has become a common feature of our public service will be minimized.

ii. The best officers should be given training functions in order to multiply talents in the public service. This requires a change of attitude by our national leaders to manpower training. The practice of entrusting training functions to public officers who are not the best will continue to frustrate even the best policy on manpower training and development in Nigeria.

1. The problem of job security for office holders must be addressed. The end-of-tenure reward for public officers should be generous enough to motivate them to better job performance. When this is done, the fear of retiring into penury will be analyzed and this will encourage our specialist to put in their best effort.

2. Undue emphasis should not be placed on certification for employment in all departments in the public service. Certification per se is not bad but there should be more emphasis on practical ability to perform a needed task. If this is done, most of the untapped pool of skills available in our traditional society will be gainfully employed in the public service to contribute to the process of national development. We should borrow a leaf from the Chinese revolution.

3. Opportunity should be created for easy movement of specialized skill from the private to the public service. This can be achieved through the operation of an open career system and generous welfare packages in the public service.

4. The government and moneybags should show greater commitment to research work by providing adequate fund and fully implementing research report submitted by the training institution and specialist.

5. Managers in public service organization should adopt the systems approach to training and the developments of staff and to personnel administration in general. Eckstrand systems approach, which we adopted, provides for a systematic approach to training and ensures training for all who need it in the public service. Staff training and development programmes in the public service are not systematic; they lack the machinery for evaluation and integration of the trainees into the system by way of proper placement and utilization of staff. Therefore we recommend that a returnee member of staff from study leave should be posted to a relevant department and given acting appointment pending the availability of a vacancy for him. That way, he will not forget the knowledge he acquired as a result of disuses.

\section{Conclusion}

Today's competitive environment requires managers or top administrators to continually upgrade the skills and performance of employees and their own. Such constant improvement increases both personal and organizational effectiveness. It makes organization members more useful in their current job and prepares them to take on new responsibilities. And it helps organization as a whole to handle new challenges and take advantage of new methods and technologies that emerge. Developing the workforce in this way involves training and development activities. The public service in Nigeria is the ideal 
agent for national development. For the public officer to carry out his role effectively there is need for proper training, retraining and utilization (placement). This can be achieved only if the government and public spirited wealthy individuals show commitment to the training needs of the public service organization by creating conducive, economic, social and political environment. Training in Nigeria suffers from the twin ills of low priority and adhocism. There is no well thought out perspective plan for training in public service. Frequently, there is no integration between training and performance or career development. Worse still training needs of the staff are seldom identified in public service in Delta State.

\section{References}

1. Akpan, J., The importance of in-service training. Nigeria: Chronicle Publishers, 1979.

2. Bateman, T. S., \& Snell, S.A., Management: leading \& collaborating in a competitive world. New York: McGraw-Hill, 2011.

3. $\quad$ Bougham, L., Education makes people easy to lead. Nigeria: African concord, 1987.

4. $\quad$ Bhagwan, V., \& Bhushan, V., Public administration. New Delhi: S.Chand \& Company Ltd, 2012.

5. Eckstrand, A.G., Current status of the technology of training. New York: John Willey and Sons’ Ltd., 1964.

6. $\quad$ French, D., Productivity improvement. New York: AMACOM, 1978.

7. Katz, D. \& Kahn, R., The social psychology of organization. New York: John Willey and Sons’ Ltd., 1966.

8. $\quad$ Koontz, K.,Management. New York: McGraw Hills, 2002.

9. Lupu, D. (2019). Cost-benefit analysis for transport infrastructure projects: Eastern european cases. Journal of Public Administration, Finance and Law, (15), 107-123.

10. Mukoro, A., Administration of the public service. Ibadan: Ababa Press Ltd., 2020.

11. Onah, F.O. (1992). Staff training and development in Nigerian Universities. Unpublished Ph.D Thesis

12. Onah, F.O., Human resource management. Enugu: Falladu publishers 2003.

13. Orobor, E.M., Ogieva, W. \& Abah, O.E., Theory and practice of public administration. Abuja: Adema Communications and publishers, 2006.

14. Williams, J. C \& Huber, G.P., Human behaviours in organization. Cincinatti Ohio: South-Western Publishers, 1986.

This article is an open access article distributed under the terms and conditions of the (i) $\odot$ Creative Commons Attribution - Non Commercial - No Derivatives 4.0 International License. 